\title{
Compound biogenic structures resulting from ontogenetic variation: An example from a modern dipteran
}

\author{
Fernando MUÑIZ GUINEA ${ }^{1 *}$, María G. MÁNGANO², Luis A. BUATOIS², Virginija \\ PODENIENE ${ }^{3}$, José A. GÁMEZ VINTANED ${ }^{4}$ \& Eduardo MAYORAL ALFARO
}

\footnotetext{
${ }^{1}$ Grupo de Investigación RNM 293 “Geomorfología Ambiental y Recursos Hídricos”, Universidad de Huelva, Huelva, España; fmguinea@uhu.es

${ }^{2}$ Department of Geological Sciences, University of Saskatchewan, 114 Science Place, Saskatoon, SK, S7N 5E2, Canada; gabriela.mangano@usask.ca; luis.buatois@usask.ca

${ }^{3}$ Department of Zoology, Faculty of Natural Sciences, Vilnius University, Ciurlionio 21/27, Vilnius 2009, Lithuania; sigitas. podenas@gf.vu.lt

${ }^{4}$ Department of Geosciences, Faculty of Geosciences \& Petroleum Engineering, University Teknologi Petrona (UTP), Bandar Seri Iskandar, 31750 Tronoh (Perak), Malaysia; gamez@unizar.es

${ }_{5}^{5}$ Departamento de Geodinámica y Paleontología, Univ. de Huelva, 21071, Huelva, España; mayoral@uhu.es

* Corresponding author
}

Muñiz Guinea, F., Mángano, M.G., Buatois, L.A., Podeniene, V., Gámez Vintaned, J.A. \& Mayoral Alfaro, E. 2014. Compound biogenic structures resulting from ontogenetic variation: An example from a modern dipteran. [Estructuras biogénicas compuestas resultantes de variación ontogenética: un ejemplo para un díptero moderno]. Spanish Journal of Palaeontology, 29 (1), 83-94.

\section{ABSTRACT}

Several families of Diptera are known to be active burrowers. Fly larvae of the genus Symplecta (family Limoniidae) were observed in a sandy substrate of an orange grove in Lepe, SW Spain. Traces produced by Symplecta display: (1), a proximal segment characterized by a winding furrow trail; (2), an intermediate part consisting of burrow segments arranged in zigzag; and (3), a distal part formed by a complex U-shaped burrow. The most complex morphology is present in the intermediate zigzag burrow system, which varies from irregularly sinuous and curved in its most proximal part to spiraled. In the fossil record, the trace would be ascribed to different ichnotaxa depending on the part preserved.

\section{RESUMEN}

Varias familias de dípteros incluyen excavadores activos. Larvas y pupas de mosca del género Symplecta (familia Limoniidae) han sido observadas en el sustrato arenoso de un campo de naranjos en Lepe, SO de España. Sus estructuras biogénicas muestran: (1) una parte proximal caracterizada por un surco sinuoso; (2) una parte intermedia formada por segmentos de madrigueras en zigzag; y (3) una parte distal formada por una madriguera en "U" compleja. La mayor complejidad se da en la parte intermedia, con trayectorias rectas, irregulares, sinuosas o curvas en su parte más proximal, y espirales en la parte distal. Si estas estructuras se encontrasen en el registro fósil, se podrían relacionar 
In fact, this is a compound trace recording multiple behavioural patterns. The winding furrow shows affinities with Helminthopsis, the zigzag burrows with Treptichnus, and the U-shaped burrow with Arenicolites. Furthermore, the spiral portion shows some similarities with Spirophycus and Spirodesmos. Interestingly, formation of these compound traces is connected with different ontogenetic stages of the producer. The winding and zigzag segments are produced, respectively, by Symplecta larvae and pupae for feeding purposes, whereas the U-shaped burrow is excavated during the end of pupal stage for protection until adulthood. In the fossil record, this incipient compound trace potentially may occur in lake-margin, fluvio-estuarine and overbank deposits, including levee, crevasse splay and pond deposits, forming part of the Scoyenia or the Mermia ichnofacies. Structures similar to those produced by modern diptera are known from freshwater ichnofaunas since the Devonian.

Keywords: Diptera, ontogeny, behaviour, modern compound traces, Spain. con diferentes icnotaxones según la parte conservada. El conjunto es una estructura compuesta que registra múltiples comportamientos: el surco sinuoso muestra afinidades con Helminthopsis, las madrigueras en zigzag con Treptichnus, la madriguera en "U" con Arenicolites, y la parte en espiral con Spirophycus y Spirodesmos. Su formación está relacionada con diferentes etapas ontogénicas del productor. Tanto los surcos sinuosos como las madrigueras en zigzag son producidas por Symplecta en los estadios de larva y pupa respectivamente, para alimentarse; la madriguera en "U", durante la fase terminal de pupa, como protección hasta convertirse en adulto. En materiales antiguos, esta pista compuesta podría aparecer en depósitos lacustres marginales, fluvio-estuarinos y de desbordamiento, incluyendo facies de dique, rotura de dique y charca, formando parte de las icnofacies de Scoyenia o de Mermia. Estructuras similares aparecen en icnofaunas de agua dulce desde el Devónico.

Palabras clave: Diptera, ontogenia, comportamiento, pistas compuestas actuales, España.

\section{INTRODUCTION}

Diptera, or true flies, are a large order containing about 200,000 known species (of which under half of these have been described), grouped in 218 families of which 43 are extinct (Blagoderov et al., 2002). Several families of flies are known to be active burrowers. In particular, neoichnologic studies have documented a wide variety of structures produced by Chironomidae, Ephydridae, Stratiomyidae, Syrphidae, Tabanidae and Tipulidae, among others (Chamberlain, 1975; McLachlan \& Cantrell, 1976; McCall \& Tevesz, 1982; Metz, 1987a, b; Mángano et al., 1996; Charbonneau \& Hare, 1998; Uchman, 2005). Diptera have been suggested as tentative producers of biogenic structures in the palaeoichnologic literature (e.g., Tarr, 1935; Metz, 1987b, 1995, 1996, 2000; Braddy \& Briggs, 2002; Uchman et al., 2004; Rindsberg \& Kopaska-Merkel, 2005; Mikuláš et al., 2012).

Traces of fly larvae and pupae of the genus Symplecta (family Limoniidae, subfamily Chioneinae) were observed on a wet, sandy substrate of an orange grove in the town of Lepe, Huelva, SW Spain. The main objectives of this study are to: (1), document recent compound traces produced by Diptera; and (2), interpret these traces in connection to ontogenetic stages of the producer. In addition, we discuss the ichnotaxonomic implications of our finding, and we place the described biogenic structures within the evolutionary framework of the Diptera.

\section{STUDY AREA AND METHODS}

The zone studied is located in an area known as Arroyo Valleforero, $3 \mathrm{~km}$ west of the town of Lepe (Huelva Province, southwestern Spain) (Fig. 1a). Arroyo Valleforero is dominated by a landscape of gullies produced from the erosion of silt and sandy sediment of Early Pliocene age (Muñiz Guinea, 1998). This soft substrate is appropriate for intense agricultural activities in connection with orange production (Fig. 1b). In particular, our observations were made on a $100 \mathrm{~m}^{2}$ area in an orange grove (Citrus sinensis Osbeck). Over 20 specimens producing compound traces were studied (Fig. 1c). Samples and photographs of specimens in larval and pupal stages were taken for classification and illustration. Observations were made between November and March.

\section{DESCRIPTION OF BIOGENIC STRUCTURES}

Three distinct morphologies are recognized from the proximal to the distal end of the trace:

\subsection{Winding furrow trail (Figs 2a-b)}

Unbranched, horizontal, unlined slightly sinuous furrows. Structures indicative of motion of the organism (such as 


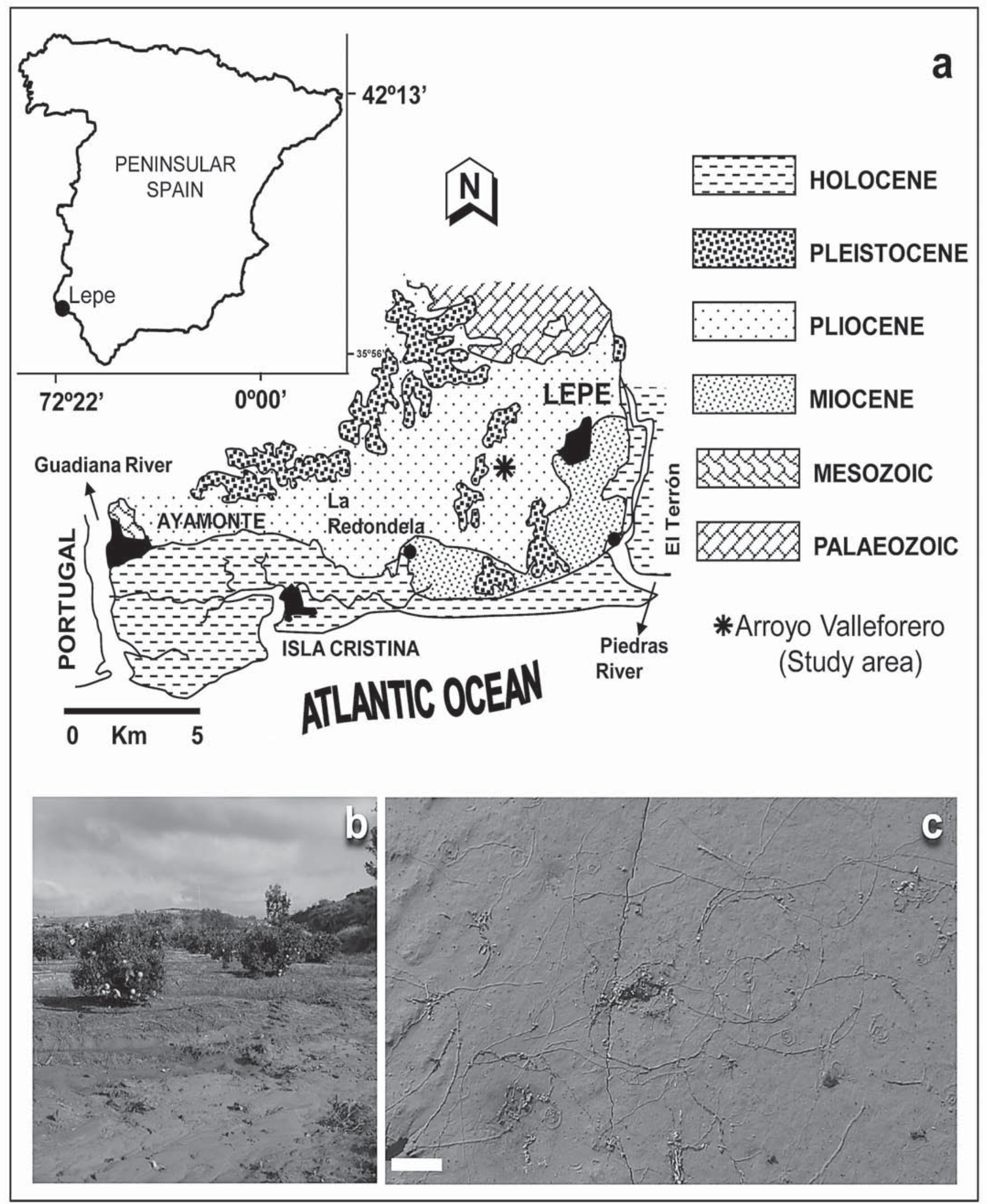

Figure 1. a) Geological map with location of the study area. b) Orange grove where the study was performed. c) General view of grove soil showing the density of occupation by bioturbating dipterans at various ontogenetic stages. Scale bar, $10 \mathrm{~cm}$. 


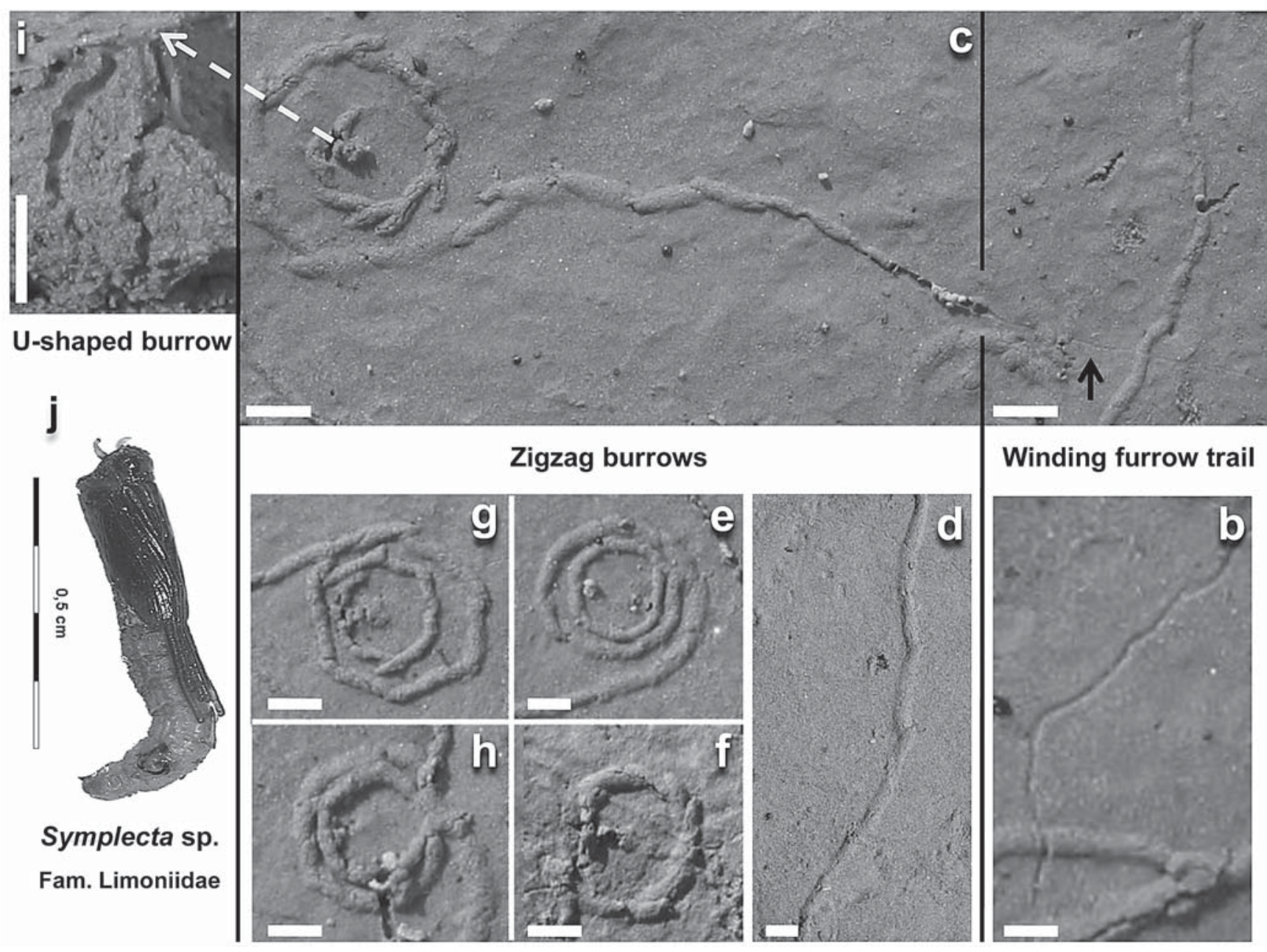

Figure 2. Different morphologies of fly larval and pupal traces, Lepe (Huelva, SW Spain). a) A winding trail (incipient Helminthopsis). b) Close-up of a winding trail. c) Straight to dextrorsal spiral zigzag burrow segment (incipient Treptichnus). d) Close-up of zigzag burrow with straight spindle-shaped segments. e) Sinistrorse spiral-shaped burrow (incipient aff. Spirophycus/aff. Spirodesmos). f) Dextrorse spiral zigzag burrows. g) Dextrorse spiral zigzag burrows. h) Sinistrorse spiral-shaped burrow. i) U-shaped vertical burrow (incipient Arenicolites). j) Fly pupa specimen belonging to Symplecta sp. (family Limoniidae). Scale bars in a-i, $1 \mathrm{~cm}$.
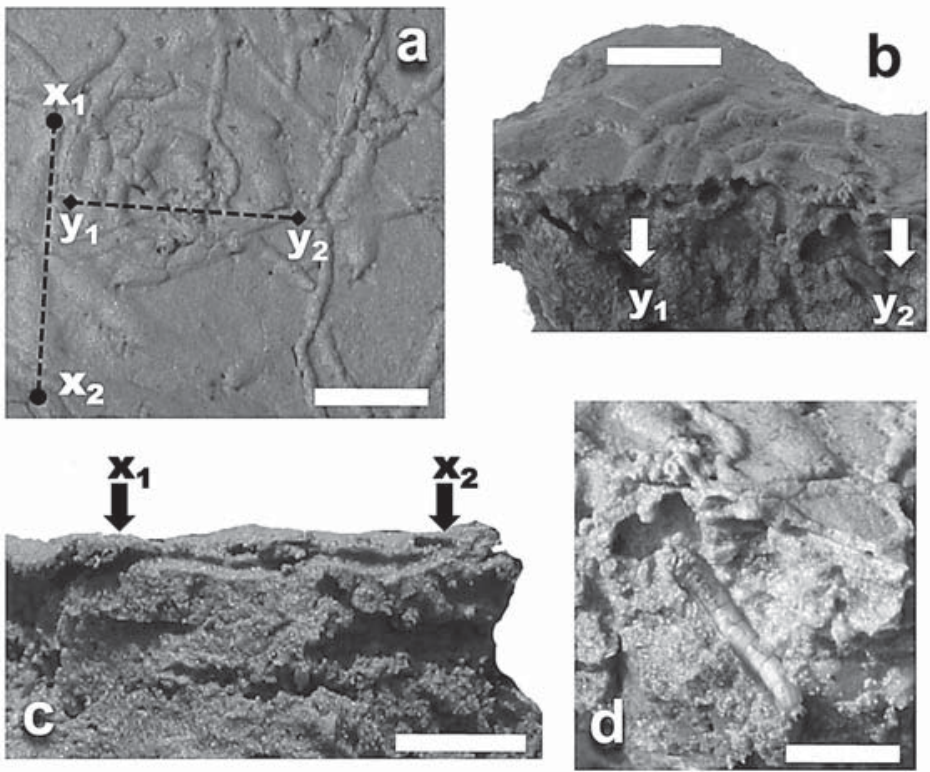

Figure 3. Sections of pupal burrows of Symplecta. a) Top view of zigzag burrows with a dextrorse spiral pattern. Two lines are indicated for sectioning the soft sediment. b) Circular cross sections of several zigzag burrow segments coiled in spiral (shown on "a"). c) Vertical longitudinal section of two zigzag segments approaching the spiral sector shown in "a". Note that path along the section is slightly sinuous, and show penetration into the sediment. d) Transitional state between the larval and pupal stages of the fly, exposed to the air after sectioning its burrow at the transitional sector between the winding furrow trail and the zigzag burrows. Scale bars, $0.5 \mathrm{~cm}$. 
sidelong, sediment accumulation or basal menisci) are absent. Width varies with ontogeny, from $0.2 \mathrm{~mm}$ in the proximal part up to $1.1 \mathrm{~mm}$ in the distal one. Maximum observed length is $13-15 \mathrm{~cm}$. Preservation is as concave epirelief.

\subsection{Zigzag burrows (Figs 2c-h)}

Horizontal, unbranched traces consisting of short, spindleshaped segments irregularly organized into a continuous zigzag pattern. The path is also irregular, evolving from straight-sinuous in its proximal part to spiral (either dextrorse Figs 2c-g-f or sinistrorse Figs 2e-h) in its distal part. Vertical longitudinal sections of the segments are slightly sinuous, and show penetration into the sediment (Fig. 3). Cross sections are circular. At the onset of the zigzag burrow shown on Fig. 2c (right part), the burrow wall is eroded thus permitting us to observe a very distinct peletoidal infill. The inner diameter is $1.0-1.5 \mathrm{~mm}$, whereas outer width is $1.2-3.5 \mathrm{~mm}$. The maximum observed length for this part of the trace is $24.7 \mathrm{~cm}$. Segments are preserved as hollow full reliefs.

\subsection{U-shaped burrow (Fig. 2i)}

Complex, unlined U-shaped vertical burrow. The two shafts (which roughly keep parallel to each other along their paths) are perpendicular to the substrate at their openings, but then they deviate from the vertical and start meandering. Thus a curved first order path and a slightly sinuous second order path can be observed on both shafts. Shaft diameter is $1.5-1.9 \mathrm{~mm}$. Maximum observed depth is approximately $2 \mathrm{~cm}$. Preserved as full relief.

\section{DISCUSSION}

\subsection{Implications for ichnotaxonomy}

Fossil representatives of this biogenic structure would be assigned to different ichnotaxa depending on the portion of the trace preserved. The winding furrow shows affinities with Helminthopsis, the zigzag burrows with Treptichnus, the spiral portion with Spirophycus and Spirodesmos, and the U-shaped burrows with Arenicolites. In terms of a Seilacherian ethological classification, the winding furrow trails (incipient Helminthopsis) belong to pascichnia, the zigzag burrow system and the spiral burrow (incipient Treptichnus, Spirophycus and Spirodesmos) to fodinichnia, and the U-shaped burrow (Arenicolites) to domichnia (Fig. 4).
The observed structures are best understood as compound traces, which result from the changing behaviour of a single producer during its ontogeny (Pickerill, 1994; Pickerill \& Narbonne, 1995). In the most common situation, such as the one documented in this study, the tracemaker behaves in distinct ways in chronological order, comprising intergradations of one ichnotaxon into another. This has been well documented in the fossil record, as illustrated by the transition between locomotion and resting traces, such as Cruziana and Rusophycus in the case of trilobites (Crimes, 1970; Mángano et al., 1996), and Protovirgularia and Lockeia in the case of bivalves (Mángano et al., 1998). However, other ethologic categories may be involved, as shown by the transition between the echinoid grazing trace Scolicia and its resting counterpart Cardioichnus (Smith \& Crimes, 1983). In other cases, transitions may occur within an ethologic category, such as the more typical cases of the crustacean dwelling burrows Ophiomorpha, Thalassinoides and Gyrolithes (Bromley \& Frey, 1974; Muñiz et al., 1995).

Although these chronological intergradations are well known from the fossil record, they are usually interpreted as behavioural changes mostly linked to the daily activities of the tracemakers. Our study documents for the first time that these intergradations may actually reflect an ontogenetic trajectory, opening a research line for the recognition of this phenomenon in the fossil record. Incidentally, these compound traces provide further information that sheds light on ichnotaxonomic debates. Our view fully agrees with that of Bromley's (1996, p. 166) perspective that "in the final analysis, it is the morphology of the trace as an expression of animal behaviour that is the basis of the name". Ichnology is forced to use a dual nomenclature, two separate names for biotaxa and ichnotaxa. Almost invariably, behavioural convergence rules out establishing a one-to-one relationship between a producer and a trace fossil. Inclusion of factors other than the morphologic expression of behaviour, such as identity of the tracemaker and depositional environment or age of the rocks, would be methodologically and conceptually flawed, because it would invariably lead to circular reasoning (see discussion in Buatois et al., 1997, and Buatois \& Mángano, 2011).

This situation is clearly illustrated by some of the zigzag burrows observed at Lepe (Figs 5a-b). These burrows are morphologically identical to Treptichnus pedum (Fig. $5 \mathrm{c}$ ), an ichnospecies whose first appearance indicates the Ediacaran-Cambrian boundary in shallow- to marginalmarine environments (Narbonne et al., 1987; Brasier et al., 1994; Buatois et al., 2013). T. pedum are most likely produced by priapulids (Vannier et al., 2010). The fact that zigzag burrows are present in strata of highly variable age, depositional environments and spectrum of fabricators is no ground for assigning such fossils to different ichnotaxonomic names (contra Dzik, 2005). 


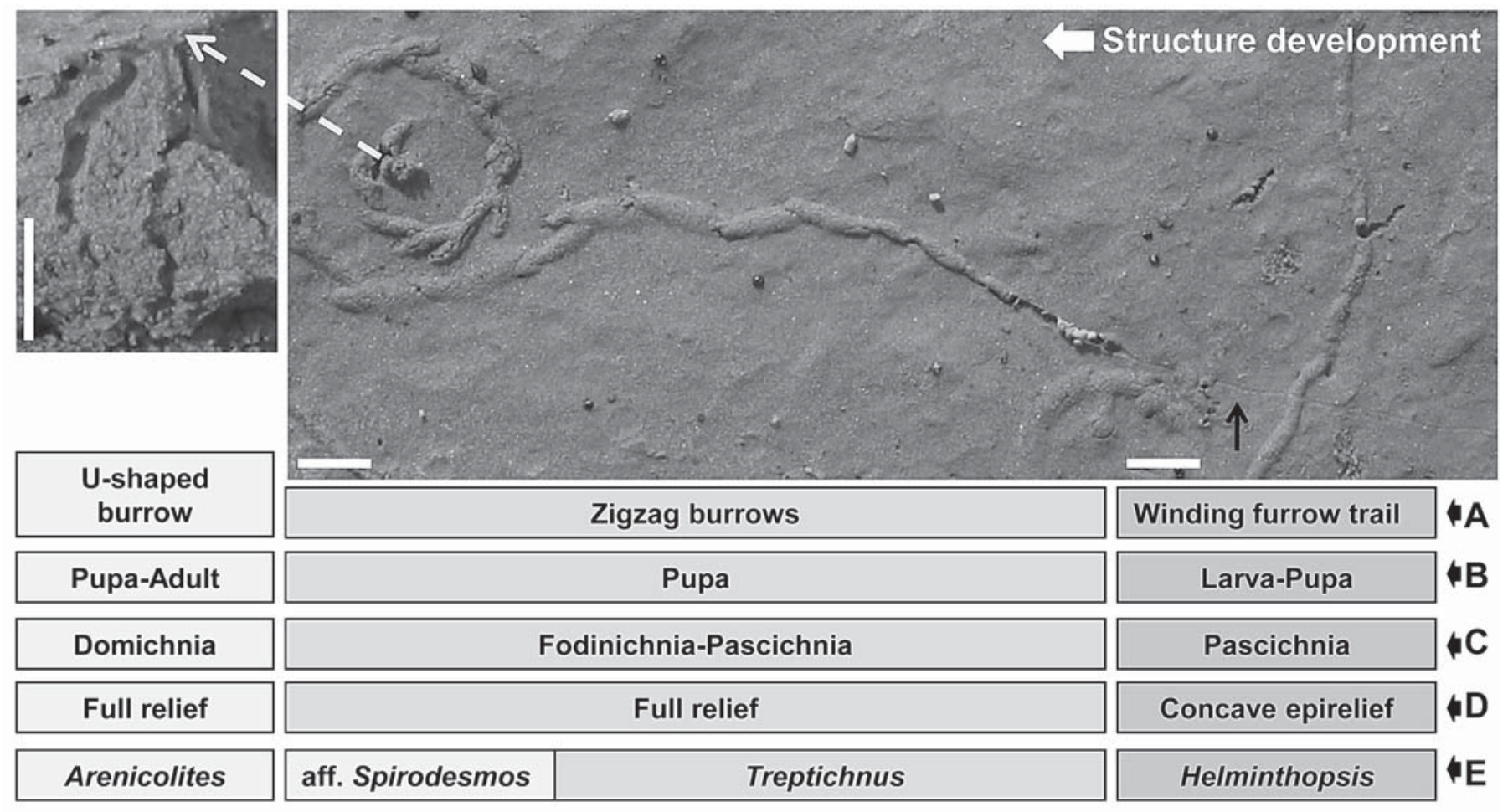

A: morphology; B: ontogenetic stages of the producer; C: ethology; D: stratinomy; E: equivalent trace fossil

Figure 4. Summary diagram with empirical and interpretative data for a particular trace made by a larva and pupa of the genus Symplecta. Scale bars, $1 \mathrm{~cm}$.

\subsection{Tracemaker, ontogeny and ethology}

Most tipulomorphs place their eggs in soils that are relatively humid or dry, and associated with a stagnant water body nearby. In the present case, the eggs were placed in a sandy substrate where humidity is constant due to artificial irrigation. Symplecta (see Fig. 2j) has a complete metamorphosic life cycle consisting of four ontogenetic stages and a larval stage consisting of four instars. Information on the European species, S. hybrida and $S$. stricta, indicates that the larva hatches from the egg between 26 and 45 days.

From a functional point of view, the structure is highly variable throughout construction, reflecting a series of behavioural changes of Symplecta that eventually are revealed by the production of a compound trace. These behaviours may have been influenced by the interplay of intrinsic factors such as ontogenetic stages and extrinsic constraints, such as substrate type. The winding furrow trail corresponds to the larval stages, that displays a progressive increase in trail width (Figs 2a-c, 6). The observed morphology suggests horizontal exploitation of the organic particles on the substrate (detritus feeding). In a subsequent phase, the organism constructs a complex infaunal burrow (zigzag burrow system), which may have been controlled jointly by sediment grain size and the size of the larvae. Symplecta may use blood pressure (through volumetric changes in hemolymph) as an excavation tool. With increased burrowing capability, the pupa is able to burrow into the sediment. Indeed, trace width doubles at the shift from a winding furrow trail to a zigzag burrow (Figs 2a-d, 6). An alternative explanation to the construction of an infaunal structure is protection from predators. At the distal end of the zigzag burrow, another sharp change is detected in shape (associated to trace width decrease) where the pupa tends to form a spiral that either is dextral or sinistral. This change in pattern suggests feeding optimization through maximum exploitation of the substrate and minimum energy costs as a likely strategy for food acquisition (deposit feeding). This transition occurs before entering in an immobile phase near the end of the pupal stage, eventually producing the adult stage within the U-shaped burrow. The width of the spiral progressively decreases until the structure disappears into the substrate (Figs 2c, e, g, h, 6).

\subsection{Environmental implications and the trace- fossil record}

The genus Symplecta (familia Limoniidae) has a worldwide distribution, and inhabits riparian and marginal lacustrine environments. In the fossil record, this compound trace of Symplecta potentially may occur in lake-margin, fluvio- 


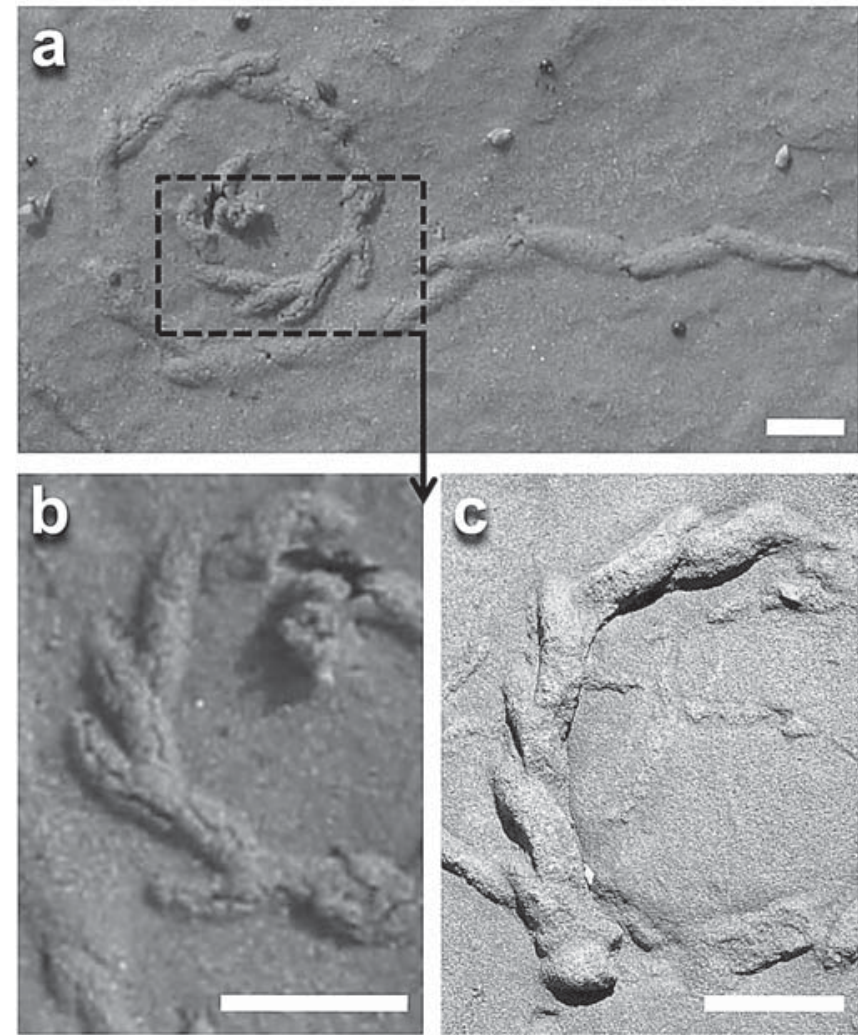

Figure 5. Similarities between the modern fly pupal zigzag burrows of Lepe (Huelva, SW Spain) and the Fortunian ichnospecies Treptichnus pedum. a) General view of a fly pupal zigzag burrow. b) Close-up of the burrow segment framed in "a" (rotated $90^{\circ}$ clockwise), identical to $T$. pedum. c) Specimen of $T$. pedum from the Fortunian, Klipbak Formation, Vanrhynsdorp Group (South Africa). Scale bars, $1 \mathrm{~cm}$.

estuarine and overbank deposits, such as those associated with levees, crevasse splays and ponds. Accordingly, such traces would form part of the Scoyenia or the Mermia ichnofacies. Unsurprisingly, similar structures to those described in this study have been recorded as common elements of freshwater ichnofaunas since the Devonian, particularly involving winding trails and zigzag burrows.

In particular, examples of the ichnogenus Treptichnus in fluvio-lacustrine and fluvio-estuarine settings are known from the Devonian of Wales (Morrissey \& Braddy, 2004; Marriott et al., 2009); Carboniferous of Argentina (Buatois \& Mángano, 1993a, b, 2003; Pazos 2000; Buatois et al., 2006, 2010; Pazos et al., 2007; Desjardins et al., 2010), Brazil (Netto et al., 2009), the United States (Archer \& Maples, 1984; Maples \& Archer, 1987; Buatois et al., 1997, 1998; Mángano et al., 2001; Lucas et al., 2004; Mángano \& Buatois, 2004; Lucas \& Lerner, 2005; Rindsberg \& Kopaska-Merkel, 2005) and Canada (Keighley \& Pickerill, 1997; Falcon-Lang et al., 2006); Permian of Antarctica (Miller \& Isbell, 2010) and the United States (Haubold \&
Lucas, 2001, 2003; Minter et al., 2007; Minter \& Braddy, 2009); Triassic of the United States (Metz, 1995, 1996); Jurassic of the United States (Metz, 1992); Cretaceous of the United States (Buatois et al., 2000); Oligocene of Switzerland (Uchman et al., 2004); and the Pleistocene of England (Gibbard \& Stuart, 1974) and Canada (Gibbard \& Dreimanis, 1978).

\subsection{Evolutionary history of diptera}

The Diptera, or true flies, represents an old lineage of holometabolous insects (Grimaldi \& Engel, 2005; Labandeira, 2005; Blagoderov et al., 2007). The mecopteroid precursors of the Diptera, as recorded by isolated wings or whole specimens with four wings, are known from upper Permian deposits (Willmann, 1989; Shcherbakov et al., 1995) and extend to the Late Pennsylvanian ( $\mathrm{Nel}$ et al., 2007). The oldest true (i.e., two-winged) diptera have been recovered from Lower Triassic strata (Blagoderov et al., 2007). Recent molecular analysis (Bertone et al., 2008) placed the origin of crown group Diptera at approximately $267 \mathrm{Ma}$ (middle Permian), marking the split between Deuterophlebiidae and all remaining Diptera. Accordingly, molecular-clock data point to a slightly earlier appearance for the crown group than the body-fossil record. Molecular data also indicate that further diversifications took place during the Mesozoic and that by the end of the Cretaceous (65 Ma) all major groups of extant lower (nematocerous) Diptera were already present (Bertone et al., 2008). Attribution of Palaeozoic freshwater Treptichnus to the Diptera remains speculative at this stage, and the most parsimonious interpretation is that the oldest freshwater zigzag structures likely were produced by other insects, reflecting behavioural convergence similar to the early Cambrian marine Treptichnus, produced by priapulids.

\section{CONCLUSIONS}

Modern fly larvae and pupae belonging to the genus Symplecta (family Limoniidae) were observed producing distinctive traces that display: (1), a proximal part characterized by a winding furrow trail; (2), an intermediate section consisting of zigzag burrows; and (3), a distal part comprising an U-shaped burrow. The zigzag burrow may vary from irregularly sinuous and curved in its most proximal part to a spiraled form distally. This structure illustrates a compound trace representing multiple behaviours during the ontogenetic stages of the producer and, if partially preserved, would be assigned different ichnotaxonomic names. The winding furrow and the zigzag burrows are produced, respectively, by Symplecta larvae 


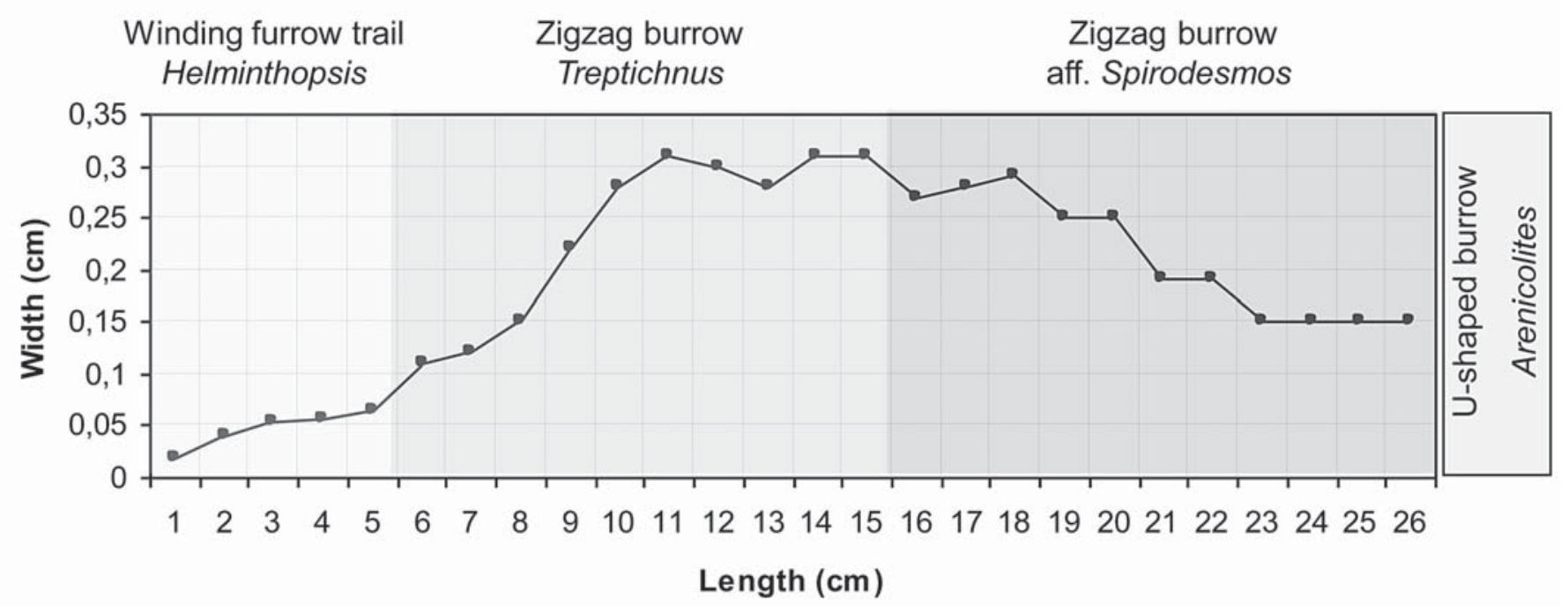

Figure 6. Length/width scatter diagram of the horizontal part of specimen illustrated in Figures 2a, c.

and pupae for feeding purposes, showing affinities with Helminthopsis and Treptichnus, respectively. By contrast, the U-shaped burrow is excavated during the end of the pupal stage for protection until adulthood, representing incipient Arenicolites. The spiral portion shows some similarities with Spirophycus and Spirodesmos. Symplecta presently inhabits riparian and marginal lacustrine environments. This is consistent with the trace-fossil record because segments of this compound trace are known in lake-margin, fluvio-estuarine transitions and overbank deposits, forming part of the Scoyenia or the Mermia ichnofacies since the Devonian. The body-fossil record and molecular-clock data place the origin of the Diptera around the Permian-Triassic boundary. Consequently, the occurrences of the oldest (pre-Permian) dipteran-like trace fossils may reflect behavioural convergence.

\section{ACKNOWLEDGEMENTS}

We thank Conrad C. Labandeira (Smithsonian Institution, Washington D.C., USA) and Radek Mikuláš (Institute of Geology, Academy of Sciences, Prague, Czech Republic) for improving the manuscript with their reviews. Financial support for this study was provided by Natural Sciences and Engineering Research Council (NSERC) Discovery Grant 311726-05/08 (L. Buatois) and Discovery Grant 31172705/08 (M.G. Mángano). Grupo de Investigación RNM293 Geomorfología Ambiental y Recursos Hídricos, University of Huelva (Spain) and the University of Andrés Bello (Concepción, Chile) provided funds to F. Muñiz Guinea. E. Mayoral thanks Grupo de Investigación RNM276 "Geociencias Aplicadas e Ingeniería Ambiental" (Gaia) de la Junta de Andalucía. J.A. Gámez Vintaned acknowledges finantial support from the projects CGL2011-24516 and Consolíder CGL2006-12975/BTE ("MURERO"; Ministerio de Educación y Ciencia-FEDER-EU, Spain). This paper is dedicated to the memory of our excellent friend Jordi Maria de Gibert, with whom we shared so many wonderful moments. Jordi: you have definitely left an amazing trace!

\section{REFERENCES}

Archer, A.W. \& Maples, C.G. 1984. Trace-fossil distribution across a marine-to-nonmarine gradient in the Pennsylvanian of southwestern Indiana. Journal of Paleontology, 58, 448-466.

Bertone, M.A., Courtney, G.W. \& Wiegmann, B.M. 2008. Phylogenetics and temporal diversification of the earliest true flies (Insecta: Diptera) based on multiple nuclear genes. Systematic Entomology, 33, 668-687.

Blagoderov, V.A., Lukashevich, E.D. \& Mostovski, M.B. 2002. Order Diptera. In: The History of Insects (eds Quick, D. \& Rasnitsyn, A.P.). Kluwer Publishers, Dordrecht, 227-240.

Braddy, S.J. \& Briggs, D.E.G. 2002. New Lower Permian nonmarine arthropod trace fossils from Nem Mexico and South Africa. Journal of Paleontology, 76, 546-557.

Brasier, M., Cowie, J. \& Taylor, M. 1994. Decision on the Precambrian-Cambrian boundary stratotype. Episodes, 17, 3-8.

Bromley, R.G. 1996. Trace Fossils, Biology, Taphonomy and Applications. Chapman and Hall, London.

Bromley, R.G. \& Frey, R.W. 1974. Redescription of the trace fossil Gyrolithes and taxonomic evaluation of Thalassinoides, Ophiomorpha and Spongeliomorpha. Bulletin of the Geological Society of Denmark, 23, 311-335. 
Buatois, L.A. \& Mángano, M.G. 1993a. Trace fossils from a Carboniferous turbiditic lake: implications for the recognition of additional nonmarine ichnofacies. Ichnos, 2, 237-258.

Buatois, L.A. \& Mángano, M.G. 1993b. The ichnotaxonomic status of Plangtichnus and Treptichnus. Ichnos, 2, 217-224.

Buatois, L.A. \& Mángano, M.G. 2003. Caracterización icnológica y paleoambiental de la localidad tipo de Orchesteropus atavus, Huerta de Huachi, Provincia de San Juan, Argentina: Implicancias en el debate sobre los ambientes de sedimentación en el Carbonífero de Precordillera. Ameghiniana, 40, 53-70.

Buatois, L.A. \& Mángano, M.G. 2011. Ichnology: Organismsubstrate interactions in space and time. Cambridge University Press, Cambridge.

Buatois, L.A., Mángano, M.G., Maples, C.G. \& Lanier, W.P. 1997. The paradox of nonmarine ichnofaunas in tidal rhythmites: integrating sedimentologic and ichnologic data from the Late Carboniferous of eastern Kansas, USA. Palaios, 12, 467-481.

Buatois, L.A., Mángano, M.G., Maples, C.G. \& Lanier, W.P. 1998. Ichnology of an Upper Carboniferous fluvio-estuarine paleovalley: the Tonganoxie Sandstone, Buildex Quarry, eastern Kansas, USA. Journal of Paleontology, 72, 152-180.

Buatois, L.A., Mángano, M.G., Fregenal-Martinez, M.A. \& de Gibert, J.M. 2000. Short-term colonization trace-fossil assemblages in a carbonate lacustrine konservat-lagerstätte (Las Hoyas fossil site, Lower Cretaceous, Cuenca, central Spain). Facies, 43, 145-156.

Buatois, L.A, Netto, R., Mángano, M.G. \& Balistieri, P. 2006. Extreme freshwater release during the late Paleozoic Gondwana deglaciation and its impact on coastal ecosystems. Geology, 34, 1021-1024.

Buatois, L.A., Netto, R. \& Mángano, M.G. 2010. Ichnology of late Paleozoic post-glacial transgressive deposits in Gondwana: reconstructing salinity conditions in coastal ecosystems affected by strong meltwater discharge. In: Late Paleozoic Glacial Events and Postglacial Transgressions in Gondwana (eds López-Gamundí, O.R. \& Buatois, L.A.). Geological Society of America Special Paper, 468, 149-173.

Buatois, L.A., Almond, J. \& Germs, G.J.B. 2013. Environmental tolerance and range offset of Treptichnus pedum: Implications for the recognition of the EdiacaranCambrian boundary. Geology, 41, 519-522.

Chamberlain, C.K. 1975. Recent lebenspurren in non-marine environments. In: The study of trace fossils. A Synthesis of Principles, Problems, and Procedures in Ichnology (ed. Frey, R.W.). Springer Verlag, New York, 431-458.

Charbonneau, P. \& Hare, L. 1998. Burrowing behaviour and biogenic structures of mud-dwelling insects. Journal of the North American Benthological Society, 17, 239-249.

Crimes, T.P. 1970. Trilobite tracks and other trace fosils from the Upper Cambrian of North Wales. Geological Journal, 7, 47-68.

Desjardins, P.R., Buatois, L.A., Mángano, M.G. \& Limarino, C.O. 2010. Ichnology of the latest Carboniferous-earliest Permian transgression in the Paganzo Basin of western
Argentina: The interplay of ecology, sea-level rise, and paleogeography during postglacial times in Gondwana. In: Late Paleozoic Glacial Events and Postglacial Transgressions in Gondwana (eds López-Gamundí, O.R. \& Buatois, L.A.). Geological Society of America Special Paper, 468, 175-192.

Dzik, J. 2005. Behavioral and anatomical unity of the earliest burrowing animals and the cause of the "Cambrian explosion". Paleobiology, 31, 503-521.

Falcon-Lang, H.J., Benton, M.L, Braddy, S.L. \& Davies, S.J. 2006. The Pennsylvanian tropical biome reconstructed from the Joggins Formation of Nova Scotia, Canada. Journal of the Geological Society, London, 163, 561-576.

Gibbard, P.L. \& Dreimanis, A. 1978. Trace fossils from late Pleistocene glacial lake sediments in southwestern Ontario, Canada. Canadian Journal of Earth Science, 15, 1967-1976.

Gibbard, P.L. \& Stuart, A.J. 1974. Trace fossils from proglacial lake sediments. Boreas, 3, 69-74.

Grimaldi, D. \& Engel, M.S. 2005. Evolution of the insects. Cambridge University Press, Cambridge.

Haubold, H. \& Lucas, S.G. 2001. The tetrapod footprints of the Choza Formation (Texas) and the Artinskian age of the Lower Permian ichnofaunas. Hallesches Jahrbuch für Geowissenschaften, B23, 79-108.

Haubold, H. \& Lucas, S.G. 2003. Tetrapod footprints of the Lower Permian Choza Formation at Castle Peak, Texas. Palaeontologische Zeitschrift, 77, 247-261.

Keighley, D.G. \& Pickerill, R.K. 1997. Systematic ichnology of the Mabou and Cumberland groups (Carboniferous) of western Cape Breton Island, eastern Canada, 1: burrows, pits, trails, and coprolites. Atlantic Geology, 33, 181-215.

Labandeira, C.C. 2005. Fossil history and evolutionary ecology of Diptera and their associations with plants. In: The Evolutionary Biology of Flies (eds Yeates, D.K. \& Wiegmann, B.M.). Columbia University Press, New York, 217-272.

Lucas, S.G., Lerner, A.J, Bruner, M. \& Shipman, P. 2004. Middle Pennsylvanian Ichnofauna from Eastern Oklahoma, USA. Ichnos, 11, 1-11.

Lucas, S.G. \& Lerner, A.J. 2005. Lower Pennsylvanian invertebrate ichnofossils from the Union Chapel Mine, Alabama: a preliminary assessment. In: Pennsylvanian Footprints in the Black Warrior Basin of Alabama (eds Buta, R.J., Rindsberg, A.K. \& Kopaska-Merkel, D.C.). Alabama Paleontological Society Monograph, 1, 147-152.

Mángano, M.G. \& Buatois, L.A. 2004. Ichnology of Carboniferous tide-influenced environments and tidal flat variability in the North American Midcontinent. In: The Application of Ichnology to Palaeoenvironmental and Stratigraphic Analysis (ed. McIlroy, D.). Geological Society, London, Special Publication, 228, 157-178.

Mángano, M.G., Buatois, L.A. \& Claps, L. 1996. Grazing trails formed by soldier fly larvae (Diptera: Stratiomyidae) and their paleoenvironmental and paleoecological implications for the fossil record. Ichnos, 4, 163-167.

Mángano, M.G., Buatois, L.A., Maples, C.G. \& West, R.R. 1998. Contrasting behavioral and feeding strategies 
recorded by tidal flat bivalve trace fossils from the Upper Carboniferous of eastern Kansas. Palaios, 13, 335-351.

Mángano, M.G., Labandeira, C., Kvale, E. \& Buatois, L.A. 2001. The insect trace fossil Tonganoxichnus from the Middle Pennsylvanian of Indiana: Paleobiologic and paleoenvironmental implications. Ichnos, 8, 165-175.

Maples, C.G. \& Archer, A.W. 1987. Redescription of early Pennsylvanian trace-fossil holotypes from the nonmarine Hindostan Whetstone beds of Indiana. Journal of Paleontology, 61, 890-897.

Marriott, S.B., Morrissey, L.B. \& Hillier, R.D. 2009. Trace fossil assemblages in Upper Silurian tuff beds: evidence of biodiversity in the Old Red Sandstone of southwest Wales, UK. Palaeogeography, Palaeoclimatology, Palaeoecology, 274, 160-172.

McCall, P.L. \& Tevesz, M.J.S. 1982. The Effects of Benthos on Physical Properties of Freshwater Sediments. In: Animal-Sediment Relations (eds McCall, P.L. \& Tevesz, M.J.S.). Plenum Press, 105-176.

McLachlan, A.J. \& Cantrell, M.A. 1976. Sediment development and its influence on the distribution and tube structure of Chironomus plumosus L. (Chironomidae, Diptera) in a new impoundment. Freshwater Biology, 6, 437-443.

Metz, R. 1987a. Insect traces from non-marine ephemeral puddles. Boreas, 16, 189-195.

Metz, R. 1987b. Recent traces by invertebrates in aquatic nonmarine environments. Bulletin of the New Jersey Academy of Sciences, 32, 19-24.

Metz, R. 1992. Trace fossils from the Lower Jurassic nonmarine Towaco Formation, New Jersey. Northeastern Geology, 14, 29-34.

Metz, R. 1995, Ichnologic study of the Lockatong Formation (Late Triassic), Newark Basin, southeastern Pennsylvania. Ichnos, 4, 43-51.

Metz, R. 1996. Nonmarine trace fossils from the Late Triassic and Early Jurassic of New Jersey. Bulletin of New Jersey Academic Science, 41, 1-5.

Metz, R. 2000. Triassic trace fossils from lacustrine shoreline deposits of the Passaic Formation, Douglassville, Pennsylvania. Ichnos, 7, 253-266.

Mikulás, R., Fatka, O. \& Szabad, M. 2012. Paleoecologic implications of ichnofossils associated with slightly skeletonized body fossils, Middle Cambrian of the Barrandian area, Czech Republic. Ichnos, 19, 199-210.

Miller, M.F. \& Isbell, J. 2010. Reconstruction of a highlatitude, postglacial lake: Mackellar Formation (Permian), Transantarctic Mountains. In: Late Paleozoic Glacial Events and Postglacial Transgressions in Gondwana (eds López-Gamundí, O.R. \& Buatois, L.A.). Geological Society of America Special Paper, 468, 193-207.

Minter, N.J. \& Braddy, S.J. 2009. Ichnology of an Early Permian tidal flat: The Robledo Mountains Formation of the Robledo Mountains, Southern New Mexico, USA. Special Papers in Palaeontology, 82, 1-107.

Minter, N.J., Krainer, K. \& Lucas, S.G. 2007. Paleoecology of an Early Permian playa lake trace fossil assemblage from Castle Peak, Texas, USA. Palaeogeography, Paleoclimatology, Palaeoecology, 246, 390-423.
Morrissey, L.B. \& Braddy, S.J. 2004. Terrestrial trace fossils from the Lower Old Red Sandstone, southeast Wales. Geological Journal, 39, 315-336.

Muñiz Guinea, F. 1998. Paleoicnología del Neógeno Superior en el Sector Suroccidental de la Cuenca del Guadalquivir, Área de Lepe-Ayamonte (Huelva). Tesis Doctoral (unpublished), Universidad de Huelva.

Muñiz, F., Mayoral, E. \& Martín, M. 1995. Pistas fósiles intergradacionales en el Mioceno superior del sector suroccidental de la Cuence del Guadalquivir. Libro de Comunicaciones de las XI Jornadas de Paleontología, Tremp (Lérida), 119-122.

Narbonne, G.M., Myrow, P., Landing, E. \& Anderson, M.A. 1987. A candidate stratotype for the PrecambrianCambrian boundary, Fortune Head, Burin Peninsula, southeastern Newfoundland. Canadian Journal Earth Science, 24, 1277-1293.

Nel, A., Roques, P., Nel, P., Prokop, J. \& Steyer, S. 2007. The earliest holometabolous insect: a "crucial" innovation with delayed success (Insecta Protomeropina: Protomeropidae). Annales de la Société Entomologique de France (N.S.), 43, 349-355.

Netto, R.G., Balistieri, P.R.M.N., Lavina, E.L.C. \& Silveira, D.M. 2009. Ichnological signatures of shallow freshwater lakes in the glacial Itararé Group (Mafra Formation, Upper Carboniferous-Lower Permian of Paraná Basin, S Brazil). Palaeogeography, Palaeoclimatology, Palaeoecology, 272, 240-255.

Pazos, P.J. 2000. Trace fossils and facies in glacial to postglacial deposits from the Paganzo basin (Late Carboniferous), central Precordillera, Argentina. Ameghiniana, 37, 23-38.

Pazos, P.J., di Pasquo, M. \& Amenabar, C.R. 2007. Trace fossils of the glacial to postglacial transition in the El Imperial Formation (Upper Carboniferous), San Rafael Basin, Argentina. In: Sediment-Organism Interactions, a Multifaceted Ichnology (eds Bromley, R., Buatois, L.A., Mángano, M.G., Genise, J. \& Melchor, R.). Society of Economic Paleontologists and Mineralogists, Special Publication, 88, 137-147.

Pickerill, R.K. 1994. Nomenclature and taxonomy of invertebrate trace fossils. In: The Palaeobiology of Trace Fossils (ed. Donovan, S.K.). John Wiley and Sons Ltd., Chichester, 3-42.

Pickerill, R.K. \& Narbonne, G.M. 1995. Composite and compound ichnotaxa: a case example from the Ordovician of Québec, eastern Canada. Ichnos, 4, 53-69.

Rindsberg, A.K. \& Kopaska-Merkel, D.C. 2005. Treptichnus and Arenicolites from the Steven C. Minkin Paleozoic footprint site (Langsettian, Alabama, USA). In: Pennsylvanian Footprints in the Black Warrior Basin of Alabama (eds Buta, R.J., Rindsberg, A.K. \& Kopaska-Merkel, D.C.). Alabama Paleontological Society Monograph, 1, 121-141.

Shcherbakov, D.E., Kashevich, E.D. \& Blagoderov, V.A. 1995. Triassic Diptera and initial radiation of the order. International Journal of Dipterological Research, 6, 75-115.

Smith, A.B. \& Crimes, P.T. 1983. Trace fossils formed by heart urchins a study of Scolicia and related traces. Lethaia, 16, 79-92. 
Tarr, W.A. 1935. Concretions in the Champlain Formation of the Connecticut River Valley. Bulletin of the Geological Society of American, 46, 1493-1534.

Uchman, A. 2005. Treptichnus-like traces made by insect larvae (Diptera: Chironomidae: Tipulidae). In: Pennsylvanian Footprints in the Black Warrior Basin of Alabama (eds Buta, R.J., Rindsberg, A.K. \& Kopaska-Merkel, D.C.). Alabama Paleontological Society, Monograph, 1, 143-146.

Uchman, A., Pika-Biolzi, M. \& Hochuli, P.A. 2004. Oligocene trace fossils from temporary fluvial plain ponds: An example from the freshwater molasse of Switzerland. Eclogae Geologica Helvetiae, 97, 133-148.

Vannier, J., Calandra, I., Gaillard, C. \& Zylinska, A. 2010. Priapulid worms: Pioneer horizontal burrowers at the Precambrian- Cambrian boundary. Geology, 38, 711-714.

Willmann, R. 1989. Evolution und phylogenetisches System der Mecoptera (Insecta: Holometabola). Abhandlungen der Senckenbergischen. Naturforschenden Gesellschaft, $544,1-153$. 
